\title{
Debenture as Alternate Scheme of Raising Investment Fund and Its Prospects under Ethiopian Company Law
}

\author{
Lantera Nadew Anebo *
}

\begin{abstract}
With a view to attracting investors, the Government of Ethiopia has offered a variety of incentives and financing schemes. However, the incentives or loan options can be inadequate, susceptible to corrupt practices and inaccessible to many business undertakings. This article examines other possible options of raising investment fund privately from the general public by issuing debt security (debenture). Instead of looking for hand outs of governments or sole reliance on bank loan, investors can raise investment fund from the general public -even beyond national borders- by offering debenture bonds for public subscription. A debenture is debt security that entitles its holder to collect periodic interest until the loan is paid back. Compared to bank loans, raising investment fund through the instrumentality of debentures is more advantageous. The rate of interest, the volume of loan needed for running business, and the time for repayment can be determined by investors. Moreover, the loan is not generally subject to collateral. This article highlights the nature, form, and class of debenture under Ethiopian law, and discusses the legal requirements for the issuance of debenture, the amount of money that can be raised by issuing debentures, the status of debentures in Ethiopia, and legal safeguards for repayment of the loan.
\end{abstract}

\section{Key terms}

Debenture $\cdot$ Bond $\cdot$ Investor $\cdot$ Floating charge $\cdot$ Creditor $\cdot$ Debtor $\cdot$ Ethiopia

DOI http://dx.doi.org/10.4314/mlr.v13i3.1

This article is licensed under a Creative Commons Attribution-NonCommercialNoDerivs (CC BY-NC-ND)

\section{Suggested citation:}

Anebo, Lantera N. (2019), 'Debenture as Alternate Scheme of Raising Investment Fund and Its Prospects under Ethiopian Company Law', Mizan Law Review, Vol. 13, No. 3, pp. 333-362.

* Lantera Nadew Anebo, Scientiae Juridicae Doctor (SJD), LL.M (Commercial Law), LL.M. (Intellectual Property and Technology Law, LL.B. Assistant Professor, School of Law and Federalism, Ethiopian Civil Service University.

ORCID: https://orcid.org/0000-0003-4336-4026

The Author is grateful to Ms. Mahder Zeru Kidanu, Senior Legal Officer, National Bank of Ethiopia for her unreserved assistance of this work. 


\section{Introduction}

This article sheds light on the basic rules, principles, and statutory requirements that need to be observed to issue debenture in Ethiopia. It compares 'debenture' and 'bond' and addresses the confusion regarding their salient features and relationships. Some jurisdictions take the two debt securities alike while others make a vivid distinction. The Commercial Code rarely uses the term 'bond,' but there are numerous laws that apply the term 'bond' in a manner that seems different from debt security in the traditional sense.

Ethiopian law is silent regarding the status of debenture holding creditors. There is also the need to examine whether Ethiopian debenture holders are secured or unsecured creditors. If the former is true, a question arises with regard to the nature of security. In UK, for example, debenture holders are secured by a floating charge, ${ }^{1}$ i.e. a kind of company security that hovers over all present and future assets of the company. In French ${ }^{2}$ and OHADA law, bondholders are secured with a specific security. However, in the United States, debenture holders are generally unsecured creditors that simply rely on issuer's general creditworthiness. ${ }^{3}$

In Ethiopia, one may argue that debenture holders are unsecured creditors. It appears equally possible to argue that, unless a specific guarantee is given, Ethiopian debenture holders are shielded by a floating charge. This article examines potential issues that are related to the issue of debentures in Ethiopia by using doctrinal research methodology. It aims at giving some insight to business lawyers, managers and investors to look for a viable option of raising fund for investments and potential expansions of business undertakings. The first two sections of the article deal with the need for debentures in the Ethiopian context and the salient features of debentures. Sections 3 and 4 examine the legal procedures in the issuance of debentures and issues relating to safeguarding the interest of debenture subscribers. Section 5 deals with the blend between debenture holder security and ease in business operations relating to the status of debenture holders among company creditors.

\footnotetext{
Frequently used acronyms:

DBE Development Bank of Ethiopia

OHADA The Organization for Harmonization Business Law in Africa

NBE National Bank of Ethiopia

${ }^{1}$ H.R. Hahlo \& M. J. Trebilcock (1977). Hahlo's Casebook on Company Law, (2 ${ }^{\text {nd }}$ ed. London, Sweet \& Maxwell Let) p. 237.

${ }^{2}$ Gilles Endreo, France's Draft Ordinance and Decree of 30 January 2017 for Improving the Development of French Law Governed Bond Issue, White \& Case LL.P. 05 Apr. 2017.

${ }^{3}$ Tim Lemeke, How Debentures Work (Understanding the Difference \& Similarities, $<$ https://www.thebalance.com/how-do-debenture-bonds-work-4160251>. (Accessed $03 / 15 / 19)$
} 


\section{The Need for Debenture in the Ethiopian Setting}

The traditional sources of investment fund are inadequate to meet the rapidly increasing demand for finance. Cognizant of the wide gap in need for investment and available financing schemes, the Government of Ethiopia has been allocating fund to the priority sectors through the Development Bank of Ethiopia (DBE), and other agencies, but these channels of funding are overburdened with high demand for investment loan that seems to have exposed the agencies to corrupt practices. ${ }^{4}$ Most government affiliated channels of finance are not open to all sectors of the economy, and to all investors. As an alternative to these channels, aspiring businesses and investors can invite the general public to take part in the fundraising process that can benefit all stakeholders. $^{5}$

The usual way of raising fund from the general public is offering corporate securities to potential investors. Subject to limitations in the capital clause of memorandum of association, or contrary stipulations in the articles of association, a share company can issue as many shares as possible to finance a projected venture. In emerging economies, like Ethiopia, share companies can play a pivotal role by enabling investors to raise fund from the general public, including small capital holders who may contribute even a tiny share in the future big company. ${ }^{6}$ This feature of a share company empowers enthusiastic investors to run capital intensive ventures that cannot be feasible otherwise. The possibility to raise a large sum of money from potential investors, beyond the

\footnotetext{
${ }^{4}$ According to Ethiopian Observatory, the investigation revealed, "mismanagement loan, favouritism, impropriety on the part of recipients surfaced." See The Ethiopia Observatory, $<$ https://ethiopiaobservatory.com/>; $<$ (http://addisfortune.net/articles/results-fromgambella-commercial-farms-disappointing/> Investigation reports reveal that, billions of birr was used for unrelated purposes. Id. Consequently, the loan remained uncollectable, and the Government has changed its lending policy. As recently reported by the Governor of the NBE, almost $40 \%$ of the loan granted by DBE is Non-Performing Debt (NFD). This is much higher than the tolerable level of NFD. Id.

${ }^{5}$ Fundraising for the construction of the Grand Ethiopian Renaissance Dam (GERD) is a live experience that plausibly illustrates how massive capital ventures can be financed by small capital holders, irrespective of the economic status of contributors. Though largely motivated by nationalism and agitated by political considerations, fundraising for the Dam proves the possibility of running development projects without looking for foreign hands that are often backed by leverages that are not suitable to Africa. See Tonderay Uered, Can Africa Fund its Own Growth? <https://www.un.org/africarenewal/magazine/august2015/can-africa-fund-its-own-growth>. (Accessed 08/15/18).

${ }^{6}$ As the personality of investors is not a requirement in a share company, an unlimited number of investors can partake in the fundraising process. This is the most critical quality of share companies over other forms of business organizations in Ethiopia.
} 
confines of the national border, makes share company the most attractive form of business organization in Ethiopia. ${ }^{7}$

Raising fund from potential investors is not limited to start-ups, but companies already in business may decide to increase capital by offering shares for public subscription. Established "big companies" can expand or extend the contours of business, or struggling companies can revive their venture by injecting additional fund. The dynamic nature of business, ever-changing customer taste, and advancing technology dictates companies to continuously reform the way of doing business, improve quality of products offered to customers, or to restructure businesses in tandem with the ever-changing circumstances. Accommodation of change usually needs additional investment.

To raise sufficient capital, a company may look for the engagement of potential investors. Ordinarily, capital may be raised from the general public by offering shares for public subscription. But this possibility of raising investment capital is not always available, or not easy to get, and meet the immediate financial need. ${ }^{8}$ On account of a range of causes and reasons, a share company may not be able to offer new shares to the public. ${ }^{9}$ Consequently, a prudent

\footnotetext{
${ }^{7}$ However, transborder share subscription is only possible if the field of investment is not reserved to citizens. With a view to safeguard young Ethiopian companies and the Ethiopian economy, some fields of investment are reserved only to Ethiopians. Thus, if a field of investment is reserved only to Ethiopians, shares cannot be offered to foreigners. Some areas of investment, like banks and other financial institutions, foreigners of Ethiopian origin can subscribe shares provided that they pay the subscription price in hard currency. Foreigners of Ethiopian origin are persons who hold foreign passport and Ethiopian origin card (commonly known as yellow card) can subscribe shares of Ethiopian banks.

${ }^{8}$ Unlike the Anglo-American system, in Ethiopia, a company cannot retain shares for a future offer. Under Ethiopian company law, there is no difference between authorized, issued capital, and subscribed capital. Thus, all of the shares have to be offered for public subscription, and no share shall be outstanding, meaning, all the shares have to be issued and subscribed. (Commercial Code of 1960, Art. 312 (1)(a)). Consequently, to issue new shares to the public, the company has to get another authorization, which requires fulfilment of general deliberation in extraordinary general meeting, and amendment of the company's constitution. After passing over a range of procedures, the company can offer shares, but it is a time-consuming procedure that cannot respond to the immediate demands of the fast-changing business situation.

${ }^{9}$ Issue of new stock necessarily requires amendment of constitutional documents of the company, and amendment may require a rigorous procedure that may not be easily fulfilled. (See Art. 462 cum 464 - 470 of the Commercial Code of 1960). A share company may also have shareholders with diverse views on the increase of capital by issuing new shares. The deadlock may not allow the company to issue new stock by amending capital section of its Memorandum of Association.
} 
board may look for other alternate schemes of raising investment capital with a view to attracting diverse groups of investors.

A company may seek additional investment from shareholders by raising the par value of shares already held. If the company has already exhausted the possibility of issuing new shares, or if it is not possible due to other reasons, it may simply increase the par value of shares. However, as increasing par value of shares generates liability to shareholders, a shareholder unwilling to bear further liability can challenge the move, unless the increase is financed by other schemes. ${ }^{10}$ The law does not require shareholders to make additional investment, and such compulsion is contrary to their inherent membership rights. ${ }^{11}$ Thus, as an exception to the corporate democracy rule, the majority cannot force dissenting minority shareholders to bear additional liability. ${ }^{12}$

Owing to a variety of exigencies, a company may not be able to raise fund either by offering new shares or raise capital by increasing the par value of shares. Even if the company can issue new shares or raise par value of existing shares, these schemes of fundraising are " [...] seldom adequate to meet [...] long term financial needs of a company." 13 If the company has exhausted all avenues of raising fund through shares, it would be left with the option of

${ }^{10}$ Capitalizing reserves may be one of such schemes, but it cannot be expected at a time when the company is in a dire situation. (See Art. 482 cum 454 of the Comm. Code of 1960). If the company does not have a reserve fund, the only possible option would be to persuade shareholders to pay additional money on the shares they own or think for other possible options.

${ }^{11}$ Commercial Code of 1960, Art. 425(2)(b).

12 Alteration of capital clause of memorandum of association can be approved by an extraordinary general meeting. The quorum and decision making majority of extraordinary general meeting has to be constituted (Commercial Code, Art. 425). Increase of capital by increase of par value of shares modifies the capital section of the memorandum of association. Thus, in accordance with Art. 464 (3) of the Commercial Code of 1960, an increase of capital by increasing the par value of shares has to pass by an extraordinary general meeting. Typically, a special majority vote (two-third) suffices to pass resolutions in an extraordinary general meeting but resolutions increasing the par value of shares, unless the increase value is financed by a capitalization of reserves, can only be passed by a unanimous vote. Thus, a single dissenting shareholder can make the majority powerless to increase capital. But, dissent is not a veto that absolutely bars increase. The company can keep on increasing, but the dissenting shareholder's shares have to be bought back at the prevailing market price. (Commercial Code of 1960, Art. 464/3).

${ }^{13}$ See National Council of Education Research and Training, Issue and Redemption of Debentures, $<$ http://ncert.nic.in/ncerts/1/leac202.pdf $>$, (Emphasis added) (Accessed $03 / 22 / 19)$. 
borrowing. ${ }^{14}$ Borrowing is a traditional remedy to overcome the need for finance. Depending upon the nature of business and interest of creditors, a company may acquire a short-term or long-term loan.

Needless to say, money may be borrowed from individuals, banks, and other lending agencies. In some cases, the amount of money needed may be huge that cannot be financed from a single source, or banks and other financial sources may require a collateral that is hard to furnish. In some cases, even if the company meets stringent procedures and requirements for assurance of repayment, banks and private financial institutions may not be willing or be able to lend the entire amount of finance needed to run capital-intensive projects. Depending upon the gloomy prospects of a company, borrowing from banks may not be easy, or it may be subject to high-interest charge that would drain the capital of the company thereby placing the very existence of the company under question.

To overcome the uncertainty, the board of directors may thus opt for a less bureaucratic form of financing. To this end, entrepreneurs who run business as a share company can invite the general public to lend them money by offering debenture with a promise to pay the loan back at a specific future date, or keep the investor earn interest indefinitely as far as the company is a going concern, or until the occurrence of a predetermined condition to redeem the debenture. Just like shares, debentures may be offered to anyone including foreigners. On the contrary, acquiring loan from foreign sources is not easy, as repayment should be effected in hard currency. Under the current Ethiopian law, not all companies are privileged to access foreign loan. ${ }^{15}$

14 Private equity and venture capital can be other alternates that would fill domestic financing gap but, given the volatile nature of emerging economies, foreign financial sources cannot be expected to remedy a pressing need for finance.

${ }_{15}$ As the regulatory body of the financial sector, the National Bank of Ethiopia (NBE) strictly controls access to foreign loan. Currently, in accordance with NBE's External Loan Directives, only entities that can earn hard currency in their regular business may be allowed to get foreign loan. For instance, banks can earn foreign currency by selling their shares to foreign citizens with Ethiopian origin who can subscribe shares in hard currency. Further, Ethiopian banks can open branches abroad thereby earning foreign currency. Other companies, too, like tour operating companies, hotels that can earn foreign currency in their regular business can also get foreign loan privately. The Ethiopian Airlines often gets foreign loan as it can pay the loan in hard currency without seeking hard currency from NBE. Thus, if there is the possibility for an entity to earn hard currency by selling its products (goods or services), the NBE can allow foreign loan. When Ethiopian companies start issuing debentures, only companies that can get loan from foreign sources can offer transboundary debentures. Before issuing debentures for foreign subscription, the companies should get authorization form NBE. When it comes to debenture subscription contract, the NBE may comment on the specific contents of the contract. 
In debentures, however, the required sum of money may be split into several units that would enable every potential lender to participate in financing a big project by issuing debt security. The issue of a debt security (debenture) is thus the most viable scheme that enables the general public to participate in the fundraising process ${ }^{16} \mathrm{~A}$ debenture acknowledges indebtedness of the borrowing company. Debenture holders are creditors of the company; and same as banks, they normally earn interest computed in accordance with a pre-determined rate until the loaned money is fully paid back, or converted into stock as the case may be.

The Commercial Code of 1960 (hereinafter the Code) embodies rules governing the issue of debentures, but this part of the Code has never been tested in practice. In its current state, it may not be surprising if an investor or a corporate manager is unaware of the possibility and legality of raising fund from the general public by issuing debt security (debenture). But the demand for issue of debenture has already started in Ethiopia. As an interview with a Senior Legal Officer at the National Bank of Ethiopia (NBE) ${ }^{17}$ indicates, a company in Mekelle, Tigray sought authorization for issue of debentures. But the relevant government office at the Ministry of Trade was not sure as to the procedures of issue, and directed the company to the National Bank of Ethiopia, which also denied the authority to regulate issue of debenture. Owing to such uncertainty on the issue of debenture, the attempt has not materialized. This article can encourage relevant authorities and companies to reconsider the issue and facilitate the issue of debentures in Ethiopia.

Instead of solely depending on bank loan that demand the fulfilment of rigorous procedures, cumbersome bureaucracy, and require unaffordable collateral that would weaken the business, ${ }^{18}$ a company can diversify sources of investment fund by offering debentures to the general public. Debentures may be issued for a long period of time, and in some cases may be non-interest bearing, ${ }^{19}$ or perpetual. ${ }^{20}$ The Code does not provide a time limit within which

16 Although the purpose and status of holders of debt security is different from equity security (share), with regard to the means of raising the company's fund from the general public, the process may be analogous to public offer of shares. A document titled as 'debenture,' may be offered to the public. A huge loan can be split into several small indentures so that everyone would be able to participate in the lending process.

${ }^{17}$ Interview with Mahder Zeru, Senior Legal Officer at the Legal Department of National Bank of Ethiopia

${ }^{18}$ Mesfin Zegeye (2014), 'Access to Finance Still a Problem in Ethiopia: World Bank,' Addis Business Vol. XII No.1. Jun. 2014, (Editorial). Private commercial banks in Ethiopia charge collateral valued at Birr 2.40 for every Birr 1 given credit.

${ }^{19}$ For example, where company shares are highly demanded and shares cannot be offered for public subscription on the ground of pre-emption right, outsiders can step into the company by subscribing convertible debentures aiming to be members of the company 
debentures are to be redeemed. The time of redemption depends upon the terms of issue that may vary depending on classes, forms of debentures, and the interest of parties involved. The issuing companies can design a form and class of debenture as it can attract potential lenders. ${ }^{21}$

With view to attract investors who wish to earn interest indefinitely (irredeemable debentures), the company may issue perpetual debenture. It appears fair to question whether perpetual debenture holders are really creditors or members of the company. Making loan to a company (as debenture holder) has some merits and demerits. Creditors earn a tiny portion of the company resources while members are 'owners' of the company, and can decide on the fate of the company. Creditors are entitled to earn a fixed interest even if the company has no return.

Weighing the merits and demerits, investors can prefer debentures to shares. Debenture holders are always creditors until the debentures are redeemed or changed into shares. Thus, indefinite holding of debentures cannot change their status -a debenture holder is always creditor of the issuing company no matter how indefinite the time is. The rate of interest of debentures may vary depending upon its class. Yet, the interest rate should attract potential lenders because it is presumably higher than the rate of interest one can earn by depositing money in a bank. Elucidation of nature and significance of debentures as possible sources of corporate finance appears helpful to the emerging Ethiopian business community.

when convertible debentures are converted into shares in accordance with the terms of issue. The possibility of being member of a successful company may be an incentive for a zero interest loan through debenture. In this scheme, a company can get loan without paying interest. However, this does not mean that all convertible debentures are noninterest bearing. Depending upon terms of issue, a company can use all available tools that would attract potential investors (funders).

${ }^{20}$ In India, for example, perpetual debentures may be issued. According to Section 120 of the Indian Companies Act, "A condition contained in any debentures ... shall not be invalid by reason only that thereby, debentures are made irredeemable or redeemable only on the happening of a contingency, however remote, or on expiration of a period, however long." (Bharat's Companies Act as by: Companies (Amendment) Act, 1996 (5 of 1997). In Ethiopia too, a perpetual (irredeemable) debenture may be issued as a class of debentures. A perpetual debenture is a debenture as it meets all the qualities of debenture. Debenture holders, unless terms of debenture is changed by agreement, can collect interest as long as the debtor company is a going concern. When the company dissolves, debenture holders as creditors can get the original loan and unpaid interest, as the case may be. On the possibility of issuing of perpetual debenture, see, for example, Avtar Singh (1996), Company Law, (Eastern Book Co., Lucknow, 11 ${ }^{\text {th }}$ ed.), p. 363; Paul L. Davies (1997), Gower's Principles of Company Law (6 ${ }^{\text {th }}$ ed.), p. 323. A quote by Davies states, “... debentures in their popular meaning may be made irredeemable." Id. p. 324.

${ }^{21}$ Commercial Code of 1960, Art. 434. 


\section{The Nature of Debenture and Underlying Concepts}

A debenture is a debt security ${ }^{22}$ that entitles its holder to earn periodic interest or confer other forms of privilege as stated in the debenture certificate or set forth by law. ${ }^{23}$ Debenture holders are creditors of the company. ${ }^{24}$ Debentures can be subscribed directly from the company or from the stock exchange or underwriters, as the case may be. ${ }^{25}$ Subject to contrary stipulation and terms of issue, debentures, like shares, are resalable. ${ }^{26}$ Debenture holders, without the need to wait for a maturity date, can resell their right evidenced in the debenture certificate to anyone, often at a profit. ${ }^{27}$ The process of issuing debentures is analogous to the issue of treasury bill that the National Bank of Ethiopia issues for monetary or fiscal policy considerations. ${ }^{28}$ Ethiopian treasury bills can be

${ }^{22}$ Harry G. Henn \& John R. Alexander (1986), Law of Corporations and Other Enterprises, published by West Academic. A share company's security may be broadly categorized into two main classes: equity security (share) or debt security (debenture). While holders of equity security are members or in some sense 'owners' of a company, debt security holders are creditors of the company.

${ }^{23} \mathrm{Ibid}$. Depending upon terms of issue, debentures may be converted into shares, thereby changing the status of a holder from creditor to the member of the company. In some cases, shares of a company may be highly demanded and may not be available for public subscription. If the possibility of converting debentures into shares is stipulated in the indenture, the debenture holder may have his/her/its debentures converted into shares.

${ }^{24}$ Hahlo \& Trebilcok supra note 1.

${ }^{25} I d .$, p. 236.

${ }^{26}$ International Bar Association (1980). Comparative Survey of Securities Law (J. Michael Robinson (ed.), p. 29.

${ }^{27}$ If a debenture is classed as to bearer, the company need not know the actual holder of the debt document. Just like paper money, the possessor of the bearer debenture is viewed as its owner. The possessor of bearer debenture can thus collect interest, take part in the debenture holders meeting or redeem the principal debt when it matures.

${ }^{28}$ National Bank of Ethiopia (NBE) acts in a delegated capacity representing the Ministry of Finance and Economic Cooperation. Akin to the issue of the treasury bill by NBE, a share company can issue debentures and offer them to anyone who meets the minimum requirements set by the issuing company. A subscriber of debenture bond can collect interest until the debenture is redeemed or converted to shares. The Renaissance Dam proves the possibility of fundraising by the contribution of diverse groups issuing a document of indenture. Developed economies have used such a scheme of debt security as an alternate source of corporate fundraising. In France, according to Gilles Endreo, “... large infrastructure projects, (i.e. motorways, wind farms and fiber-optic cabling which can no longer solely be financed by the public authorities, construction companies and banks; they too, have had recourse to the bond market through the issue of 'project bonds'." (See Endreo supra note 2. Government-issued bonds or bills are not backed (guaranteed) by an asset, but repayment is almost secure. Such documents are generally viewed as risk-free as the government will pay the debt on the due date, see:

https://corporatefinanceinstitute.com/resources/knowledge/finance/debenture-bonds/ 
issued for a short period of time -ordinarily not exceeding 365 days-, but debentures may be issued for a long period of time; or they may even be perpetual $^{29}$ so that perpetual debenture holders can collect interest throughout the operational life of the debtor company subject to the limitation in the terms of issue.

The nature of debenture, terms of issue, and the rights of the creditors may be expressed in the debenture certificate, or stipulated in the general meeting resolution that has authorized the issue of debenture. There is no consistency in the nature of security for repayment of money loaned through a debenture. As pointed out above, in some jurisdictions, debentures are unsecured while in others they may be backed by a specific or general security. Holders of unsecured debentures are unsecured creditors who may enjoy lesser priority in getting paid. ${ }^{30}$ In spite of such distinctions between secured and unsecured debenture holders, both categories of debenture holders are "entitled to payment before shareholders upon dissolution [of the company]". ${ }^{31}$

Despite continued efforts in various literature, the term debenture lacks a precise definition. ${ }^{32}$ Some authors state that the notion of 'debenture' is derived from the Latin word "debentur" which means, "are due," 33 but others relate the term with the Latin expression "debere," meaning borrow. ${ }^{34}$ In its ordinary

${ }^{29}$ Companies expecting a return in the long period of time, may issue long term, or perpetual debentures, see: https://corporatefinanceinstitute.com/resources/knowledge/finance/debenture-bonds/ See also Singh supra note 20.

${ }^{30}$ Henn \& Alexander supra note 22, p. 380. The general assurance for the subscribers of debentures is the reputation of the issuing company. "The issuing company must evidently enjoy a good reputation in the market and be of considerable size to permit the easy placement of the debentures in the market." (Int'l Bar Ass'n supra note 26).

${ }^{31}$ Henn \& Alexander supra note 22.

32 "There is no legally recognized distinction between bonds and debentures...." see Melvin Aron Eisenberg (2005). Corporation and Other Business Organizations. ( $9^{\mathrm{TH}}$ ed. ), p. 110. (See A statement of Lindly J. in British India Steam Navigation Co. v. Commissioners of Inland Revenue (Queen's Bench Divisional Court (1881)7 Q.B.D. 165; 50 L.J.Q.B.517; 44 L.T. 378; 29 W.R. 610 (Hahlo \& Trebilcock supra note 1, p. 239) reveal how court battled to grasp an exact nature of debenture. Lindley J states, "Now, what the correct meaning of 'debenture' is I don't know. I don't find anywhere any precise definition of it." Avtar Singh (1996). Company Law, (11 ${ }^{\text {th }}$ ed.), p. 353. It is not uncommon to take debenture as bond or indenture. Further, confusion in use of the term in accounting and economics adds up the confusion. Some use the term 'bond' to mean secured indenture, and use 'debenture' to mean an indenture not secured by a specific guarantee.

${ }^{33}$ Henn and Alexander supra note 22.

${ }^{34}$ See National Council of Education Research and Training (NCERT) supra note 13; see also https://www.toppr.com/guides/accountancy/issue-and-redemption-ofdebentures/meaning-of-debenture/. 
sense, a debenture is a "written acknowledgment of debt" or a "formal certification of indebtedness". ${ }^{35}$ Depending upon terms of issue, ordinarily, a debenture issuer promises to pay the sum stated in the certificate, and a periodic interest until the loan is fully paid. In this sense, as a debenture is a promise to pay a principal sum of money and its periodic interest, one may question whether a debenture is a promissory note. ${ }^{36}$

Although their purpose and the transaction involved have some shared features, a debenture is different from a promissory note. A promissory note shares some of the characteristics of money. To a limited extent, a promissory note can serve the function of money by endorsement or in some cases by mere delivery. A bearer debenture, like a bearer promissory note, can be easily transferred from one holder to the other, but all bearer debentures may not hold the features of a bearer promissory note. ${ }^{37}$ It is to be noted that the transferability of a promissory note is easier and quicker as compared to debenture. ${ }^{38} \mathrm{~A}$ promissory note is an unconditional undertaking by the maker "... to pay a sum of money only to the order of a specific person, or the bearer of [the] instrument". 39 There is thus a vivid distinction between promissory note and debenture even though their purposes appear to be similar. ${ }^{40}$

${ }^{35}$ NCERT, $I d$.

${ }^{36}$ Some Anglo-Saxon courts define debentures as promissory notes, stating, "Bonds and debentures [are ...] promissory notes issued pursuant to and governed by longer contracts [...]". See also Eisenberg supra note 32.

${ }^{37}$ While a promissory note shall contain the nomenclature, 'promissory note', a debenture should hold the word, 'debenture'. With regard to the formal contents of promissory note see Art. 823 of the Commercial Code of 1960. In accordance with Art. 824 of the Code, in the absence of the nomenclature, 'promissory note,' the document cannot be taken as a promissory note. Although Art. 433 of the Code does not express the need to mention the nature of the document, the inclusion of the word, 'debenture' appears a functional necessity. Further, any person can make a promissory note, individuals and companies whose capital is not fully paid cannot issue negotiable debentures. See Art. 429 of the Commercial Code of 1960.

${ }^{38}$ For instance, a convertible bearer debenture or a perpetual bearer debenture is not unconditional undertaking to pay the sum stated in the document. In such cases, the only possible way is either to convert the debenture into share when the condition for the conversion is met or simply collect interest if the debenture is perpetual. But the promissory note is always payable at the due date.

${ }^{39}$ Bhashyam \& Adiga (1977). The Negotiable Instruments Act, (Revised ed.), p. 56; see also Comm. Code of 1960, Art. 823.

${ }^{40}$ For example, while debentures may be converted into shares thereby making debenture holder creditor to shareholders, there is no such a possibility in promissory notes. Unlike, a promissory note, debentures may be offered for public subscription, and transacted in the stock exchange. Moreover, a promissory note may be negotiated like cheque or other negotiable instruments, but the transfer of a debenture differs from such transfers. 
With regard to the distinction between a debenture and a bond, some take bonds as "secured obligations, [but] debentures [as] unsecured obligations." However, the secured and unsecured nature of a loan is not always a point of distinction, ${ }^{42}$ as others regard an indenture a "bond" when it is not backed by a specific guarantee but issued by government or institutions having government affiliation. ${ }^{43}$ Furthermore, it is not uncommon to synonymise the term debenture, bond, or indenture. Some connote the term 'bond' as a secured debt, while they consider 'debenture' as a form of bond that is not backed by a specific guarantee for repayment. ${ }^{44}$

The terms 'bond,' 'debenture', or 'indenture' may appear similar, but actually, they are not. An indenture is "a written agreement under which bonds and debentures are issued, setting forth the form of a bond, maturity date, amount of issue, description of pledged assets, interest rate, and other terms". ${ }^{45}$ Behind every debenture or bond, there is indenture. W. Bratton explains the nature of bond or debenture as follows:

[A bond or debenture is] a promise by the borrower to pay a specified amount on a specified date, together with interest at specified time, on the terms and subject to the conditions spelled out in a governing indenture [....] Some of the governing terms and conditions will be set out on the face of the [bond or debenture]. Most terms, however, will be in the indenture that governs the instrument and will be merely referred to on its face. ...[I]n practice both financial and legal writing ... use 'bond' as a generic term for all long term debt securities. ${ }^{46}$

${ }^{41}$ Eisenberg, supra note 32;

${ }^{42}$ For instance, in India, "debentures include ... bonds or any other instrument of a company evidencing a debt, whether constituting a charge on the asset of a company or not." Section 2(30) of the Companies Act of 2013.

${ }^{43}$ In British India Steam Navigation Co. vs. Inland Revenue Commissioners (1881) 7 QBD 165 , Lindely J remarked, "We know that there are various kinds of instruments commonly called debentures. You may have mortgage debentures, which are charges of some kind on the property. You may have debentures which are bonds; and, if this instrument were under seal, it would be a debenture of that kind. You may have debentures which are nothing more than an acknowledgment of indebtedness." See also Hahlo \& Trebilcock supra note 1, p. 239.

44 Tim Lemeke, How Debentures Work (Understanding the Difference \& Similarities, $<$ https://www.thebalance.com/how-do-debenture-bonds-work-4160251>

(Accessed 03/15/19); see also Henn \& Alexander, supra note 22.

${ }^{45}$ Black's Law Dictionary $6^{\text {th }}$ ed.

${ }^{46}$ W. Bratton (2003), Corporate Finance -Cases and Materials ( $5^{\mathrm{TH}}$ ed.), pp. $175-76$, noted in Eisenberg supra note 32. 
French law takes the term 'bond' to mean debenture. ${ }^{47}$ In France, not only multinational companies but small and medium enterprises also issue bonds to alleviate capital constraint. In the words of Endreo, "[f]or issuers, the bond market is no longer the exclusive preserve of large issuers. Medium sized companies -traditional devotees of bank finance- have turned to the capital market in order to benefit from Private Placement (Euro PP)..." ${ }^{48}$ In this sense, the word "bond" is used in a manner that is exactly similar to the term, 'debenture' in Anglo Saxon legal system. Under French law, “... large infrastructure projects which can no longer solely be financed by the public authorities, construction companies, banks [...] too, have had recourse to the bond market through the issue of "project bonds". 49

Similarly, the Organization for Harmonization Business Law in Africa (OHADA) uses the term 'bond' instead of 'debenture'. ${ }^{50}$ Apart from using the term 'bond' and expressing the requirement for the guarantee, Articles $779-821$ (governing bond) are substantially similar to the provisions of the Ethiopian Commercial Code of 1960 . OHADA requires a company to allocate a specific security for payment of the bond loan at the general meeting that has decided for the issue of bond. ${ }^{51}$ If a bond is issued by government or institutions affiliated to government, (such as the bond for the Grand Ethiopian Renaissance Dam), there is little difference between secured and unsecured bond because the payment of the loan is essentially not doubtful. In such cases, the level of certainty of getting paid is high.

In Ethiopia, government-issued debt securities, including treasury bills, are generally termed as bond. The Grand Ethiopian Renaissance Dam (GERD) Bond is a recent government-issued indenture that is widely circulated all over the nation. It is not secured with a specific guarantee, but its payment is almost certain. Ethiopia's Commercial Code makes some mention about the term 'bond', but its exact nature and meaning remains unclear. ${ }^{52}$ Article 432 of the

\footnotetext{
${ }^{47}$ See Gilles Endreo, supra note 2.

${ }^{48}$ Ibid.

${ }^{49}$ Ibid

${ }^{50}$ Art. 779 of OHADA states, "Bonds shall be negotiable instruments which, for the same issue, shall confer the same rights to a claim for the same face value." The Organization for the Harmonization of Business Law in Africa, Uniform Act Relating to Commercial Companies and Economic Interest Group (translation). Provisions of OHADA governing bond are largely identical to the provisions of the Commercial Code of 1960 dealing with debenture apart from the requirement of express security.

${ }^{51}$ See Art. 815 of OHADA.

52 The Commercial Code of 1960 does not supply a legislative definition to the term debenture or bond. Art. 429 of the Code starts with a prohibitive rule that bars issue of negotiable debenture by companies that have not published an annual balance sheet or by individuals. Subsequent legislation formally defines the expression 'bond' but in different
} 
Code envisages the possibility of issuing "premium bonds and bonds at a discount.' The provision generally conveys a message of similarity between the terms 'bond' and 'debenture'. ${ }^{53}$ Yet it does not clearly settle the issue. It is true that a debenture may be issued at a premium like shares or issued at its par value depending upon the nature of business and financial prospects of the issuing company. But while debentures may be issued at a discount, shares cannot. ${ }^{54}$

The Amharic version avoids the confusion by using a generic expression

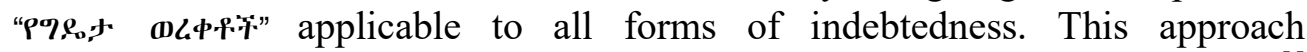
encompasses the terms bond and debenture as a document of indebtedness. ${ }^{55}$ However, this generates another complexity because the Amharic version appears to mingle rights incorporated in the documents with the document itself. In reality, a document certifying one's indebtedness, or rights incorporated therein are not the same. The document is evidence for the existence of rights of the creditor and obligations of the debtor, but it is neither a right nor an obligation. This is confusion in terms ${ }^{56}$ which has necessitated the attempt to distinguish between "certificate of indenture" and rights envisaged therein.

contexts. Use of expressions, like 'performance bond,' deepens the confusion. Performance bond has nothing to do with debt security - it is rather a guarantee system. In the sense of debt security, the notion of 'bond' is a scheme available for raising fund.

${ }^{53}$ The Grand Ethiopian Renaissance Dam (GERD) Bond is a debt security. It is unsecured debt (for the sum stated in the bond certificate) that the government has promised to pay on the due date. Similarly, the National Bank's treasury bill is also referred to as a bond. The treasury bill is not secured by specific security. In this case, the term 'bond' and 'debenture' may thus be used interchangeably. Lindley $\mathrm{J}$ in British India Steam Navigation Co. v. Commissioners of Inland Revenue expressed the same concern stating, "You may have debentures which are bonds ...". See Hahlo \& Trebilcok supra note 1, p. 239.

${ }^{54}$ A company cannot issue its shares at a discount, (below par value) because in a limited liability company share is the only guarantee to the investors in the company. Reduction in the value of share is thus impermissible, as it results in reduction of the company's capital. With a view to shield the interest of corporate creditors and the public, reduction of capital has to follow rigorous procedures that are set forth in the Code. First, the decision to reduce capital has to be made by extraordinary general meeting and consent of creditors has to be secured in advance; or the debt has to be paid or payment has to be guaranteed by a specific charge. See Arts. 484-494 of the Commercial Code of 1960 regarding specific requirements that need to be met to reduce capital.

${ }^{55}$ Commercial Code of 1960, Art. 432 uses the term bond. The Amharic version is very

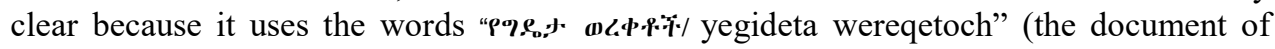
indenture). In effect, Ethiopian courts will not be troubled to distinguish whether a given document is a bond or debenture. In all cases, it is a document of indenture.

${ }^{56}$ The Amharic meaning of the notion of debenture (yegideta woreqet) and certificate of debenture (yegideta sened masreja) appear to mean a paper -literally, both wereqet and masreja are documents evidencing rights incorporated therein, but actually in practice, the two expressions are not alike. 
Although this may appear an academic exercise, a clear distinction is significant to realize the nature of the debt securities and the document that embodies and proves the security.

While debenture is a scheme whereby the issuing company raises fund by promising to pay the sum of money in accordance with terms of issue, indenture is a certificate that embodies the rights and duties arising from the schemedebenture. While the notion of debenture is analogous to the term "share", debenture certificate serves the function of share certificate. Thus, as expressions 'share' and 'share certificate' are not alike, ${ }^{57}$ the notion of debenture is more than a mere certificate of debenture. Like a share certificate, a debenture certificate is a proof of possession or ownership of rights stated therein. ${ }^{58}$

In addition to debenture, a company may owe a variety of debts that may be evidenced by a certificate of indebtedness. For instance, a share company may issue promissory note or other forms of negotiable or non-negotiable instruments acknowledging indebtedness. Ethiopian companies have not yet used all possibilities of raising corporate finance; and, in effect, the issue of distinguishing debentures and other forms of debt instruments has not yet surfaced in courts. Other jurisdictions have confronted this issue, and have devised the means of distinguishing between debentures and non-debenture indebtedness. In case of doubt, the court will critically examine the contents of the document. ${ }^{59}$

In Ethiopia, it is not hard to distinguish a debenture from commercial instruments. If a document is a debenture certificate, it has to satisfy the elements stated in Art. 433 of the Commercial Code. Similarly, if it is a promissory note, the requirements enumerated in Art. 823 of the Code shall be satisfied. The same is true to other commercial instruments. ${ }^{60}$ These provisions provide the requirements that must be shown on the face of the respective

\footnotetext{
${ }^{57} \mathrm{~A}$ non-lawyer may use the terms share and share certificate interchangeably. To a lawyer, especially to a company lawyer, the distinction is not hard to realize. The term "share" refers to bundle of rights and interests that a shareholder can enjoy. Similarity, a debenture holder, though not identical to the rights and interests of shareholder, has rights and interests against the creditor company. A right or an interest, thus, is not a document the document is simply proof of the right, or interest one can seek against the debtor company.

${ }^{58}$ According to Art. 433 of the Commercial Code of 1960, debenture certificates shall show name of the issuing company, its objects (activities it actually runs or plans to operate in the future), location of the head office, place of registration of the company, the date of formation of the company and its life span and other information.

${ }^{59}$ Signh, supra note 20.

${ }^{60}$ Art. 735 of the Commercial Code of 1960 enumerates words to be expressed in bill of exchange. A bill of exchange shall contain the words "bill of exchange." (Art. 735(a). Therefore, in practice there is no problem to identify the nature of document.
} 
documents. Failure to specify the nature of the documents and other mandatory requirements as required by law renders them invalid. ${ }^{61}$

\section{Issuance of Debentures in Ethiopia and Magnitude of Fund}

\subsection{Who may issue debenture in Ethiopia?}

With a view to protect the public, borrowing by the instrumentality of negotiable debenture to raise fund is only available to entities that meet strict requirements under the law. In Ethiopia, only companies that can issue transferrable securities can offer debentures for public subscription. ${ }^{62} \mathrm{~A}$ transferable security is a security that can be transferred by negotiation. Thus, a transferable security is a negotiable instrument. ${ }^{63}$ It may include transferable documents other than commercial papers (cheque, promissory note, bills of exchange) and documents of title to goods. ${ }^{64}$ Like commercial instruments, transferable securities can be transferred from one person to another either by endorsement or delivery.

There is no authoritative definition of transferable security in the Code, but it may include, "[...] bond, debenture, note or certificate or other evidence of indebtedness, issued by a corporation or by a government or political subdivision thereof with interest coupon or registered form [...]" ${ }^{65}$ According to Davies, company securities may be broadly classed into share and debenture. ${ }^{66}$ While a share is equity security, a debenture is debt security ${ }^{67}$ Transferability of securities may be exceptionally restricted, but this cannot vitiate the very nature of security. As a rule, shares of a share company are freely transferable, but this quality of shares may be exceptionally restricted. However, a restrictive clause cannot absolutely bar transferability of shares. ${ }^{68}$ Nor would it affect rights of innocent third parties who may be affected by unpublished restrictive clauses.

${ }^{61}$ For instance, if a document is meant to be a bill of exchange it has to specify the mandatory enumeration of Art. 735 of the Commercial Code of 1960 (Art. 736); Almost the same point is stipulated in Art. 824 of the Comm. Code. Thus, if the mandatory requirements of Art. 823 are absent, the document cannot be viewed as a promissory note (Art. 824 of the Comm. Code of 1960).

${ }^{62}$ Individual persons, including sole proprietors, partnerships, joint venture, and a private limited company cannot issue transferable securities. With regard to prohibition pertaining to private limited company, see Art. 510(3) of the Commercial Code of 1960. Under Ethiopian law, transferable securities are negotiable instruments. (Commercial Code of 1960, Art. 715(2).

${ }^{63}$ Commercial Code of 1960, Art. 715(2).

${ }^{64}$ Ibid.

${ }^{65}$ Black's Law Dictionary, $6^{\text {th }}$ Ed.

${ }^{66}$ Davies supra note 20, p. 299.

${ }^{67}$ Ibid.

${ }^{68}$ See Art. 333(3) of the Commercial Code of 1960. 
As private limited companies hold some of the features of partnerships, shares of a private limited company are not freely transferable.$^{69}$ Thus, a private limited company cannot issue debenture. ${ }^{70}$ Similarly, partnerships and private persons cannot issue negotiable debentures. ${ }^{71}$ However, business organizations and individuals that cannot issue negotiable debentures can issue a non-negotiable debenture. ${ }^{72}$ A non-negotiable debenture is like a simple acknowledgment of debt that cannot be transferred and may not be taken as a debenture in real sense.

To issue debenture, an Ethiopian share company, has to meet certain minimum requirements that are meant to safeguard public interest. First, the company's capital shall be fully paid. Normally, a company's capital is the only guarantee for repayment of company's debt. If a company borrows money from external sources before collecting its collectible debt, that will affect the interest of creditors. Second, the financial worthiness and prospects of the company shall be verified by its annual financial reports that are attached with the prospectus that accompanies public offer of debentures. ${ }^{73}$

Financial reports are documents that reveal the financial position of the company. The most frequent financial reports are the income statement and balance sheet. The latter depicts the company's assets, debts, and capital. Thus by looking at the balance sheet, one can observe the actual financial status of the company. Publication of financial statements would assist potential debenture

${ }^{69}$ Like partnerships, to transfer shares of a private limited company, shareholders holding $75 \%$ of the voting shares shall give consent.

${ }^{70}$ In accordance with Art. 510(3) of the Comm. Code, a private limited company, cannot issue transferable security. Similarly, partnerships cannot issue any form of security.

${ }^{71}$ Comm. Code of 1960, Art. 429.

${ }^{72}$ Reverse reading of Art. 429 of the Commercial Code of 1960.

${ }^{73}$ See Art. 318 of the Commercial Code. If the prospectus discloses any misstatement or holds fraud persons, there will be joint and several liablity to debenture holders who lent money on the basis of the wrong or deceptive information. The defrauded debenture holders can cancel the transaction or invalidate the contract with the possibility of seeking compensation if damage is incurred as a result of the fraudulent dissemination. A company cannot issue debenture at its formative stage. The minimum period in which a company can issue debenture is after the lapse of one year of its formation. This assertion is based on the requirement to publish an annual financial report. Financial reports will be published at the end of the fiscal year that is expected to be mentioned in the articles of association. On the basis of financial position report, experts of the Ministry of Trade or regional bureaus of trade and industry -as the case may be- may investigate the business and its future prospects that may determine the possibility of issue of the debenture. 
subscribers to assess the financial condition of the company. This enables potential creditors to make an informed decision. ${ }^{74}$

Financial reports will also help the Ministry of Trade or appropriate regional offices check the fulfilment of legal requirements for the issue of debentures, including whether the capital was fully paid. If the company's capital is not fully paid, the authority may deny authorization for the issuance of debentures. The old French law was exactly similar to the requirements of the Ethiopian Commercial Code of 1960. But currently, a stock company (sociétés par actions) can issue bond even where financial reports are not published, but with a guarantee of another company that has issued two balance sheets. ${ }^{75}$

\subsection{The magnitude of fund that can be raised through debenture and guarantee for repayment}

A company is not absolutely free to issue an unlimited number of debentures or derive unlimited volume of money through debentures. The law does not expressly cap a maximum amount of debentures, but it cannot be infinite, as the total sum of debentures cannot exceed the paid-up capital of the company. ${ }^{76}$ In a share company whose liability is limited to its assets, capital is the only guarantee for repayment of company debt. Thus, if share companies were allowed to issue debenture beyond paid up capital, the company's creditors (debenture holders) would be unable to recover their money. Consequently, a share company can issue debentures only if all of the shareholders have fully paid up their pledged capital contributions. This safeguards the public from potential risks.

If a company is set up with minimal paid-up capital and borrows a huge sum of money through debentures, the company might carry out the business without

${ }^{74}$ Potentially creditors have to be sure that they would get their money and its fruits (interest). Publication and attachment of financial reports to the prospectus helps the public to make an informed decision.

${ }^{75}$ Arts. 228-39 of the French Commercial Code. See Marc - Etinne Se'bire \& Mariam Issad, The Modernization of French Law on Bond issues, CMS Publications, (03/22/19) https://cms.law/en/FRA/Publication/The-modernisation-of-French-law-on-bond-issues

${ }^{76}$ In Ethiopia, as all the shares issued by the company have to be subscribed, subscribed capital is equal to the authorized capital. Thus, authorized capital may be more than paidup capital, especially at the formative stage of the company. For example, the authorized capital of Industrial Parks Corporation is Ten Billion Birr, while paid-up capital is Two Billion Five Hundred Million Birr. (See Art. 6 of the Industrial Parks Development Corporation Establishment Council of Ministers Regulation, Regulation No. 326/2014, Federal Negarit Gazette 21 $1^{\text {st }}$ Year No. 2 December 5, 2014 Addis Ababa). For the purposes of computing the amount of debentures, we don't have to worry in distinguishing authorized, subscribed or paid up capital. If any sum on shares of a company is outstanding - i.e. not fully paid the company cannot issue debenture as full payment of shares subscribed is a mandatory requirement. 
the worry of loss. However, this is a very speculative business that would risk only creditors. The law, therefore, rightly prohibits the issue of negotiable debentures before the capital is fully paid, and, in principle, the value of debenture certificates cannot exceed the value of the aggregate paid up capital. Thus, actually paid-up capital -not merely shares- safeguard the public interest and the interest of creditors.

In very limited cases, a company may exceptionally issue debentures in excess of its paid up capital. ${ }^{77}$ An excess issue shall satisfy the legal safeguards specified in the Code. ${ }^{78}$ First, the excess debenture should be guaranteed either by the company's immovable property, registered securities or securities issued or guaranteed by the State, or by annuities. ${ }^{79}$ In this regard, one may fairly question how a company's asset, in respect of which debentures already issued, can be encumbered with mortgage.

Unless it was acquired from other sources, a company's immovable property is part of its paid-up capital. Yet, in certain cases, a company may acquire donation or may have financed the purchase of properties from non-capital funds like profit or reserve fund ${ }^{80} \mathrm{~A}$ property contributed to the company or financed from a sum of money constituting capital is part of paid-up capital, but specific security affords better security to individual debenture holders. If the excess issue of debentures is secured by a property constituting part of the company's capital, then by implication, some of the debentures would not be represented by the company's capital.

A question arises whether this does not contravene the requirement of limiting the maximum issue of debentures to the amount of paid-up capital. Specific security of debenture holders by the company's immovable property or company's security (that is taken as a portion of paid-up capital) makes the purpose of the requirement of issue of debenture within the limits of paid-up capital superfluous. There are safeguards in this regard. If the excess issue is guaranteed by mortgage of the company's immovable property, the extent of excess issue shall not be beyond two-thirds of the value of the mortgaged property. This would safeguard the possible effect of depreciation of the value of property or price fluctuation.

${ }^{77}$ Commercial Code of 1960, Art. 430.

${ }^{78} \mathrm{Id}$, Sub art. 1 .

${ }^{79}$ If the immovable property is sold, debenture holders will get paid from the proceeds of the sale of the immovable property. Thus, debenture holders, in this case, can get paid even before the due date or can get alternative security.

${ }^{80}$ In company law, capital is the totality of the value of shares subscribed. Thus it is a sum collected from shareholders or promised by shareholders to pay whenever the company makes the call. Reserved funds or profit acquired by the company do not constitute capital. 
Excess issuance of debentures can also be secured by a guarantee of intangible assets (incorporeal chattels). A security may be a right evidenced in a document entitling its holder to convert the rights into cash at any time either by endorsing the documents to someone else or selling them in the security market. ${ }^{81}$ A security to guarantee issue of debentures exceeding capital of the company shall be registered or guaranteed or issued by the government and the date of the redemption shall not be earlier than the date of redemption of the debenture guaranteed. Thus where a debenture is issued for indefinite period of time, the security is irredeemable. Any form of registered security may be given as a guarantee for payment of the money borrowed by issuing debentures. If it is a registered share, it has to be a share of another company, as a debenture issuer cannot guarantee a debenture loan with its own shares.

As a share company cannot be a member of itself, shares of a debtor company cannot guarantee an excess issue. Hence, the shares that may be furnished as guarantee for the excess issue shall be shares of another company to which the debenture issuer is a member. Similarly, a company can guarantee excess issue with debentures it has got from another company. Governmentissued securities like treasury bills or other forms of securities guaranteed by the government can also serve as assurance for the excess issue of the debenture. Moreover, state or public authorities' annuities can guarantee an excess issue. Government annuities are periodical payments that the government pays for the life of someone. ${ }^{82}$

If the excess issue of debentures is guaranteed with securities, the document incorporating rights in the securities shall be deposited in the bank, ${ }^{83}$ and if the security is an annuity, it shall be blocked. But bailment of securities with a bank is contrary to the rules of the pledge. Security of movable property normally requires the pledge to be delivered to the pledgee, but with regard to securities guaranteeing excess issue of debentures, the law requires bailment with banks a third party holder. Bailment with banks indeed gives a maximum level of security to the excess issue of debentures.

Apparently, as exception to the exception, a company can issue debentures in excess of paid-up capital without specific security where the company is a real

\footnotetext{
${ }^{81}$ See Davies supra note 20. Thus, shares, bonds, debentures, treasury bills are securities.

${ }^{82}$ Annuity is different from pension. It is not common practice, but it is possible to grant annuities instead of a pension. To secure an excess issue with annuities, the issuer of debenture may be a beneficiary or the latter may guarantee an excess issue for the benefit of the debenture issuer.

${ }^{83}$ In accordance with Art. 2832(2) of the Civil Code, this is bailment. A bailed security has to be kept until the obligation it guarantees is discharged.

N.B: This provision deals with pledge.
} 
estate loan or agricultural mortgage company. ${ }^{84}$ The purpose of this exception appears to enable companies that finance vital projects to freely raise fund beyond the confines of restrictive rules. This may be taken, as an incentive to engage in crucially essential ventures.

\section{Offering Debentures to the Public and Safeguarding the Interest of Debenture Subscribers}

The board of directors of debenture issuing company cannot simply borrow investment fund from the general public at will, and whenever the company needs finance. Debenture subscribers are a special category of creditors (the general public) that need special protection. Consequently, loaning through debenture requires the fulfilment of some stringent procedural and legal requirements. First, a properly conducted general meeting shall authorize the issue of the debenture. ${ }^{85}$ Unless the issue of debenture results in the amendment of memorandum or articles of association, procedures of the convening of ordinary general meeting, the quorum and decision-making majority shall be fulfilled. ${ }^{86}$ If the proposal for borrowing by issuing debentures is approved, the next procedure is to inform the general public the possibility of loan through debentures.

Procedures of the public offer of debentures follow the rules of the public offer of shares. ${ }^{87}$ In the absence of stock exchange (such as the current Ethiopian setting), debentures may be offered by any method that can reach the general public. The proposal (the advertisement) for soliciting an offer for debentures shall be accompanied by documents that can inform the public the true financial position or future prospects of the issuing company. The public shall have fair, accurate and sufficient information. The issuing company has a duty to disclose all information that can help the public make an informed decision. Nondisclosure of pertinent information or misrepresentation of the truth not only causes invalidation of the contract but would also entail joint and several

\footnotetext{
${ }^{84}$ Commercial Code of 1960, Art. 430(3).

${ }^{85}$ Id., Art. 419(2). In the normal course of things, the resolution to issue debentures does not amend the constitutive document. It is simply an ordinary business that has to be decided by an ordinary general meeting. The meeting will determine the number of debentures to be issued, par value, the volume of money to be borrowed through debentures, form and class of debenture, special privilege (if any) to the debenture holders, whether debentures may be convertible or non-convertible, redeemable or irredeemable, etc. can be decided by the general meeting. Minutes of the general meeting shall be registered in the office of registration of companies. Moreover, a copy of minutes of the general meeting shall be deposited in the office of registration.

${ }^{86}$ The date of the resolution and its register shall be mentioned in the debenture certificate. See Art. 433(d).

${ }^{87}$ Commercial Code of 1960, Art. 434 cum Art. 318.
} 
liability. ${ }^{88}$ The application for debentures and other pertinent documents may be placed at a location easily accessible to the public. Banks, post offices, and other agents can sell debenture bonds to potential lenders. The issuing company can also directly contact potential creditors.

If the interest rate on debentures is attractive and where the creditworthiness of the company is high, debentures may be highly demanded. In such cases, the number of applications for debentures may exceed the number of debentures available for subscription. An issue may arise whether a company can selectively deny some of the applications for debentures. ${ }^{89}$ The application for debenture is an offer, and acceptance of the application and issue of debenture certificate marks the conclusion of the contract. The issuing company, therefore, has no obligation to accept the application for debenture(s). But, in reality, as the personality of loaners is not a requirement, the company should not consider the character or nature of the loan investor. As far as the lenders meet the terms of issue of debentures, the company may not reject the offer. ${ }^{90}$ However, a company has no legal duty to accept an offer for debentures. A company, assessing personal character of potential creditors may under exceptional circumstances, selectively accept an application for debentures. ${ }^{91}$ Thus, if the company, based on its past experience or otherwise, has legitimate grounds, it may deny the application for debenture.

As pointed out earlier, the prospectus or advertisement for debenture subscribers shall accompany documents revealing the nature and prospects of the issuing company. Business objectives of a company may attract some corporate loaners. The business of the company may be vital to the undertaking of loaners, or it may be very significant to the local community or the nation in general. In this regard, the prospectus and annexed documents would help potential creditors to calculate the future prospects of the debtor company.

After the application for debentures is accepted, the company issues certificate of the debenture which is similar to a share certificate. Its money

The issuing company and company management may be jointly and severally liable for misrepresentation or for not disclosing pertinent information.

${ }^{89}$ This issue can easily be resolved by resorting to the general rule of formation of contracts. A person has no obligation to accept an offer. Unless the offer is accepted, there is no contract and no obligation. Hence, an unaccepted application (offer) produces no obligation.

${ }^{90}$ Technically, as there is no contract yet, a company does not need to accept all applications for debentures. There is no obligation to accept an offer. The offeree can reject it either expressly or by implication, but there is no convincing reason to refuse an offer to lend money, as far as terms of the issue are not changed. In borrowing, unless the lender intends to change terms of issue, the personality of the creditor is not essential.

${ }^{91}$ For example, a creditor with negative intentions may disrupt the business of the company. 
value (par value), nature, class, and form shall be specified in the document. ${ }^{92}$ The certificate shall reveal paid up capital of the company on the date of issue of the debenture. ${ }^{93}$ Unless specifically guaranteed, the total value of debentures issued, as highlighted in Section 3, shall not exceed paid-up capital of the company. ${ }^{94}$ This reflects the solvency of the issuing company and creates a sense of security to the lenders. Debenture certificate shall indicate the date of resolution to issue debentures, date of registration of the resolution, interest rate, the period within which the interest shall be paid, serial number of the certificate, par value of debenture, term of redemption unless the debenture is irredeemable, the amount of debentures or loan stock issued previously and not amortized, indication of the guarantee attached thereto, provisions governing the conversion (if debentures are convertible), and period of time in which the debentures may be converted into shares. ${ }^{95}$

A company depending upon the interest of potential creditors may devise numerous forms and classes of debenture with varying privileges and benefits. ${ }^{96}$ Debentures may be registered or bearer. ${ }^{97}$ Registered debentures can be transferred to another person where necessary registration formalities are complied with and when debenture certificate is delivered. ${ }^{98}$ Bearer debentures are transferred like paper money because delivery of the certificate of debenture suffices. ${ }^{99}$ Thus, a possessor of bearer debenture is presumed to be a creditor of the company. In the normal course of things, a holder of bearer debenture can exercise rights arising from the document. He/she/it can thus collect interest, participate in debenture holding meetings or have his/her debenture redeemed, or transfer it to anyone. The company is apparently aware of the number of debentures it has issued, but it does not need to know the actual owner of a bearer debenture. The ownership and location of owners of registered debentures can be found in the company's debenture register. ${ }^{100}$

As debenture is indivisible, ${ }^{101}$ one can subscribe at least one debenture. Joint ownership of a debenture, however, is possible. Joint owners of a debenture shall elect a representative who may act on behalf of all debenture holders. If no

\footnotetext{
${ }^{92}$ Commercial Code of 1960, Art. 433.

${ }^{93} \mathrm{Id}$, Art. 433 (c).

${ }^{94}$ Id Art. 430. Guarantee may be given in the company's immovable property or securities.

${ }^{95} I d$., Art. 433. Such specific terms often printed at the backside of the debenture certificate.

${ }^{96}$ Id, Art.434 cum 340.

${ }^{97} I d$, Art. 434 cum Art. 325.

${ }^{98}$ Id, Art. 341.

${ }^{99}$ Id, Art. 340(1).

${ }^{100}$ Id, Art. 360.

${ }^{101}$ Id, Arts. 434 cum 328.
} 
representative is elected, communication made to any one of the holders binds all the joint owners.

A company can design different classes ${ }^{102}$ of debentures conferring varying privileges as an incentive to attract potential creditors. The Commercial Code does not expressly envision the possibility of issuing a special preference on debentures, but in the absence of express prohibition, nothing would impede a company to devise different classes of debentures with preferred rights. ${ }^{103}$ Thus, a company may issue preference or ordinary (common) debentures. A preference debenture entitles its holder to enjoy a preferential right. The most usual classes of debentures are redeemable or irredeemable debenture. ${ }^{104}$ The company may redeem redeemable debenture at a specified time envisioned in term of issue. On the date of redemption, the company will pay back the debt it had borrowed and take back the debenture certificate.

Debentures may also be convertible or non-convertible. Convertible debentures may be converted into shares. ${ }^{105}$ Terms of issue of debentures should show the nature of the debenture and conditions in which the conversion may be exercised, the number of shares that will be exchanged with the debenture, and fulfilment of any attached obligation thereto. Non-convertible debentures may be changed into convertible debentures by a resolution of the general meeting. ${ }^{106}$ If the general meeting passes a resolution affecting the rights of debenture holders, a special meeting of debenture holders is expected to be convened and decide on the fate of general meeting resolution.

Like shares, debentures may be transacted in the stock market. Transferability and assignability makes debentures different from ordinary debts. ${ }^{107}$ Depending upon the business and prospects of the company, debentures may be sold in excess of par value. A debenture holder, therefore, can transfer or dispose it at any time like any transferable security, and does not need to hold it perpetually or wait until the fixed period of redemption. Debentures may also

102 Art. 434 of the Commercial Code of 1960 does not mention Art. 335 of the Code, but the possibility of issuing convertible or non-convertible debentures is expressed in Art. 433 (h). This provides some clue on the possibility of issuing classes of debenture in Ethiopia. Art. 434 cum Art. 340 point out the possibility of issuing bearer and registered debentures.

${ }^{103}$ Depending upon demand for debentures on the stock market and urgency for finance, a company's marketing department may apply its ingenuity to exploit all possibilities of raising fund.

${ }^{104}$ Hahlo \& Trebulocock supra note 1.

105 Ibid.

${ }^{106}$ See Commercial Code of 1960, Arts. 419(2), 433(h).

${ }^{107}$ Id, Art. 434 cum 340. 
be pledged to secure the performance of an obligation. Like shares, debentures may be subjected to usufruct. ${ }^{108}$

After all the debentures are subscribed, debenture holders meeting shall be conducted. The company may convene the meeting and help debenture holders elect their representative. ${ }^{109}$ Debenture holders meeting is a special meeting and has to fulfil the quorum and decision making majority as set forth in the Code. ${ }^{110}$ The meeting may be ordinary or extraordinary. The former is a regular meeting that may be periodically scheduled ${ }^{111}$ whereas extra-ordinary debenture holders meeting can be called whenever the company proposes to vary rights or duties of debenture holders or when the company proposes to adopt a resolution that would affect the interest of debenture holders in any form. ${ }^{112}$ Finally, debenture holders can appoint an agent to represent their interest in the company, or all debenture holders may authorize a given entity to act on behalf of the general body of debenture holders. ${ }^{113}$ The possibility of acting through agency is a helpful procedure that would allow non-resident creditors to conduct periodic follow up.

\section{The Status of Debenture Holder Security among Creditors in Ethiopia}

As indicated above, the Commercial Code does not allow issue of debenture unless the authorized capital is fully paid. Where the company, exceptionally wishes to offer debentures beyond paid-up capital, the excess issue has to be guaranteed with a specific security. ${ }^{114}$ Moreover, the company that has issued debenture cannot reduce capital unless the debenture is redeemed. ${ }^{115}$ As can be inferred from Art. 430 of the Commercial Code and subsequent provisions, one can argue that the legislative intent denotes that debenture holders are secured with the capital of the company.

\footnotetext{
${ }^{108}$ Id, Art. 434 cum 329.

${ }^{109}$ Id, Art. 436.

${ }^{110} I d$, Art. 439.

111 An ordinary debenture holders meeting often deliberates on the interest of debenture holders managing enforcement of loan agreement. (Art. 437 (2) of the Commercial Code of 1960 .

112 See Art. 438 of the Commercial Code of 1960.

${ }^{113} \mathrm{Id}$, Art. 442. Debenture holders have to be vigilant in the business of the debtor company. They have to be sure that the company keeps its business and assets to pay back the loan and its periodic interest. In other words, a company has to be solvent in order to discharge its loan obligation.

${ }^{114}$ Id, Art. 430(1) (b).

${ }^{115}$ Id, Art. 431.
} 
Considering debenture holders as secured creditors necessitates careful understating on the nature of their security ${ }^{116}$ regarding issues such as whether debenture holders can claim prior payment from the proceeds of the sale of the company's assets that constitute capital, or demand specific security if the value of paid-up capital diminishes. An issue may also arise whether debenture holders can object a company's decision to dispose of all or part of its property constituting capital, or whether they can demand a close look at the business management, so that company's capital would be maintained. It is to be noted that debenture holders are not managers, or persons directly interested in the fruits of the business of the company -and they are not permitted to decide how the company runs its business or uses its capital. Thus, there must be clarity on the nature of security accorded to debenture holding creditors.

Under Ethiopian law, various forms of guarantees may be given to assure performance of a secured obligation. ${ }^{117}$ As the law requires a maximum issue of debentures not exceeding the value of the company's paid-up capital, the issue of personal guarantee cannot arise. Moreover, pledge cannot be expected, as it requires a pledged property to be delivered to the creditor, ${ }^{118}$ and a debenture holder does not take delivery of a portion of paid-up capital as assurance for payment of debentures. Nor does the security of antichresis become relevant because the kind of security envisioned in Art. 430 is not antichresis as the latter requires the property to be delivered to the creditor who may use it until the debt is paid. ${ }^{119}$

Performance of an obligation may also be guaranteed by mortgage ${ }^{120}$ while an immovable property remains with the debtor. Regular debenture holders are not mortgagees, as the issuer can freely dispose of properties making part of paid-up capital. They have no right to pursue the property and get prior payment from the proceeds of the sale of the company's property, unless a specific guarantee is given.

Clear understanding on the nature of security of debenture holders requires reference to comparative practices and laws of other countries. In the AngloSaxon legal system, debenture holders are protected with a special form of

\footnotetext{
${ }^{116}$ Depending of the nature of expected security, a debtor may furnish personal guarantee (surety (Art. 1920-1951 of Civil Code), guarantee of an obligation by movable property (pledge) that will be held by the creditor until the debt is discharged (Arts. 2825-2874 of the Civil Code), or guarantee given by immovable properties (Mortgage: Arts. 30413116 of Civil Code) or antichresis: Arts. 3117-3130 of the Civ. Code).

117 Ibid.

118 See Civil Code, Art. 2825.

${ }^{119}$ Id. Arts. 3117- 3130 .

${ }^{120}$ Id. Art. 3041- 3116.
} 
security called a floating charge. ${ }^{121}$ In Scotland, "[d]ebentures may be secured by a fixed mortgage, or a charge or by a floating charge". ${ }^{122}$ In other words, security may be given with a specific property, or a general undertaking may be subjected to encumbrance until debenture holders are paid. In Ethiopia, a specific (fixed) guarantee is an exceptional requirement -required only in the case of excess issue of debentures. In the United Kingdom and jurisdictions following English common law, debenture holders may be secured with a floating charge. ${ }^{123}$ Lord Macnaghten, defines a floating charge as:

... ambulatory and shifting in its nature, hovering over and so to speak floating with the property which it is intended to affect until some event occurs or some act is done which causes it to settle and fasten on the subject of the charge within its reach and grasp. ${ }^{124}$

The floating charge does not fit to any one of the definitions of Ethiopian guarantee systems. Unlike a specific (fixed) security, a floating charge hovers over all the present and future assets of the company. ${ }^{125}$ A floating charge is a very convenient form of security that does not affect use or transactions involving a property encumbered with the charge. It floats over fixed, movable, or circulating assets of the company. ${ }^{126}$ "Such assets keep changing, and a fresh charge would have to be created every time they were turned over in the course of business". 127

A company may "validly charge the whole of [its] undertaking and assets...". ${ }^{128}$ It can dispose of all or part of the property subjected to a floating charge. Unlike mortgagee or pledgee, debenture holders have no right to oppose the transaction, ${ }^{129}$ as anything the transaction brings in is also subjected to the floating charge encumbrance. Even when the company pays debt, it owes to another creditor with the proceeds of the sale; debenture holders cannot question

${ }^{121}$ Hahlo \& Trebilcock supra note 1.

${ }^{122}$ Some nations have enacted specific legislation governing floating charge. For instance, in Scotland floating charge was introduced by a Floating Charge Act of 1961. See Hahlo \& Trebilcock supra note 1 .

${ }^{123}$ Ibid.

${ }^{124}$ Lord Macnaghten in Illingworth vs. Houldsworth (House of Lords (1904) A.C. 355; 75 L.J.Ch. 739; 9; L. T., 602; 53 W.R. 115; 20 T.L.R. 633; 12 Mans, 14. See Hahlo \& Trebilcock Id., p. 242.

${ }^{125}$ Ibid.

${ }^{126}$ Davies supra note 20, p. 357.

${ }^{127}$ Singh supra note 19, p. 355.

${ }^{128}$ Sargent J in Re Benjamin Cope \& Sons Limited (1914) 1 Ch 800) Reported in (Hahlo \& Trebilcock supra note 1, p. 245).

${ }^{129}$ A floating charge accords the "degree of management autonomy to company with respect to charged assets." See Davies supra note 20, p. 363. 
the transaction. ${ }^{130}$ The security of floating charges applies only where the debt is due (debenture has to be redeemed) or where the company fails to pay interest in accordance with the terms of issue. Thus, indebtedness through debenture is the best mechanism to run unhindered business. ${ }^{131}$

When a debtor company fails to discharge its commitments to debenture holders, the floating charge crystallizes (meaning all available properties may be attached and foreclosed). After crystallization of the floating charge, the debtor loses the right to dispose of the property. ${ }^{132}$ However, if anyone or more of the company's property is already under specific security encumbrance, the creditor protected by a specific security, gets priority before debenture holders receive anything. In other words, if a property is subjected to a specific guarantee, such as mortgage or pledge, the mortgagee or pledgee will have priority over general debenture holders. Similarly, debenture holders who have a specific guarantee will have priority over general debenture holders. Regular debenture holders, however, can exercise priority over shareholders and unsecured creditors.

It is true that floating charge cannot affect transactions involving a property supposedly encumbered with the charge. The company can use or dispose of a property constituting paid-up capital in the normal course of business without any limitation. This appears contrary to the traditional meaning of real security and supposedly demeans floating charge as a form of guarantee that secures performance of a secured obligation. However, in reality, a floating charge is a form of shield that protects general debenture holders by enabling them to get priority of payment before shareholders and ordinary creditors.

In the United States, debenture holders are generally unsecured creditors. However, like other creditors, debenture holders may stipulate for a specific guarantee. Thus, unless specifically negotiated for a specific guarantee (like a mortgage or pledge), debentures are viewed as unsecured creditors. In the United States, the general understanding is that an assurance for repayment is based on the general creditworthiness of the issuer. ${ }^{133}$ In order to keep their general creditworthiness, companies normally discharge all commitments in accordance with the terms of issue. However, as pointed out earlier, bondholders are secured creditors in France, and OHADA provides a similar security.

\footnotetext{
${ }^{130}$ A notable company law author, Gower, witnesses that floating charge is a manifestation of "ingenuity of equity practitioners led to the evaluation of an unusual but highly beneficial type of security known as the floating charge." Cited in Singh, supra note 20, p. 355 .

131 Ibid.

132 Adam Pescoa, Debentures: What Are They and How Do They Work? Fleximiz, $<$ https://fleximize.com/articles/009206/debentures> (03/22/19).

${ }^{133}$ SeeTim Lemeke, supra note 44.
} 
If Ethiopian debenture holders are secured creditors, the kind of security should be viewed as a floating charge. Put simply, in accordance with the foregoing discussion, if the issue of debenture has to be within the limit of paidup capital, a specific guarantee need not be given. If paid-up capital of the company guarantees debenture holders, then it appears analogous to the AngloSaxon system of floating charge. The Commercial Code of 1960 does not use the term floating charge. Nor does it explicitly reveal the security shield of debenture holders. Yet, the rationale behind Article 430 of the Commercial Code suggests protection to debenture holders by the paid-up capital.

Security by a paid-up capital cannot be viewed as a specific guarantee as it includes all company properties, apart from profits and reserve funds. If Ethiopian debenture holders are secured with a floating charge, then exclusion of non-capital asset of the company from the property subject to the floating charge makes the Ethiopian system (of floating charge) different from the English system. While the company is a going concern, it can use its properties in any way it deems good for the success of the business. Thus, despite a floating charge encumbrance, the company can sell, donate, or use its property. If paid-up capital of the company assures repayment of the value of debentures, then a portion of paid-up capital on hand and future assets that make up a portion of paid-up capital will shield the interest of debenture holders. Should the company fail to pay the loan back, debenture holders can attach all properties that are not specifically encumbered with a charge and get paid prior to shareholders and ordinary creditors.

\section{Conclusion}

Ethiopia has to utilize all possible options available to alleviate acute shortage of financial supply. Highly regulated Ethiopian banks cannot adequately meet the ever-increasing high demand for capital to enhance job and wealth-creating investment. The Code sets forth the possibility for raising fund from the general public through debt security. This has never been used in practice although it is beneficial both to the debtor company and lender public.

Fundraising through debentures is not a new concept. It has been in practice in developed economies. Raising investment fund from the general public is very limited in emerging economies that are facing severe shortage of investment capital. Admittedly, in the current Ethiopian situation, it is not easy to raise fund from hesitant local people that are wary of losing their meagre saving, ${ }^{134}$ but a strong promotional work can change these attitudes. Small

\footnotetext{
134 This fear appears real. People have related experience in connection with fraudulent actions/inactions of share company founders/promoters leading to loss of savings and subsequent erosion of trust in different forms of raising finance.
} 
capital holders, instead of keeping money at home or channelling their money in illegal and risky ventures, can invest in legally and institutionally sanctioned ventures that would benefit all actors. Debenture holders would indeed benefit from periodic interest. Meanwhile, investors can raise sufficient fund that would enable them to run big projects. This would also benefit the economy, the government, and the public in general. 